\title{
INFLUENCE OF CUSTOMER SATISFACTION ON LOYALTY: A STUDY ON MOBILE TELECOMMUNICATION INDUSTRY
}

\author{
Md. Motaher Hossain and Nusrat Jahan Suchy \\ Institute of Business Admiistration, Jahangirnagar University, Savar, Dhaka, Bangladesh
}

Received 2013-07-15, Revised 2013-08-15; Accepted 2013-08-20

\begin{abstract}
The mobile telecommunication companies uphold their service quality and change their marketing core strategies to retain their existing customers by enhancing and optimizing the customer loyalty. Therefore, it becomes significant for telecom companies to identify factors of services that influence customer loyalty and in turn creates loyal customers by satisfying them. This present study aims to explore the influence of customer satisfaction on customer loyalty in the context of Bangladesh. This study focused on six factors such as communication, price structure, value-added service, convenience, sales-promotions and customer service. Both primary and secondary information were collected to test the pre-set hypotheses. Descriptive statistics and simple linear regression were employed to analyze the data. Result shows that five factors: communication, price structure, value-added services, convenience and customer service/care have positive correlations with customer loyalty.
\end{abstract}

Keywords: Customer Satisfaction, Customer Retention, Customer Loyalty, Mobile Telecommunication Industry

\section{INTRODUCTION}

Economic growth in Bangladesh has contributed significantly to improvements in the quality of life and spending power of an increasing share of the population (Hossain, 2010a). Today, telecommunication is an inseparable part of our everyday life. Besides telephone, now-a-days mobile phones are playing a great role to communicate from one place to another place. The phone is not only used for making calls, among many other functions it is used for communicating through text-messages, multi-media messages, as well as to connect us to the internet. The opportunities that lie in the telecom market seem endless and the growing demand for mobile telephony systems is creating a world-wide market. Actors in this industry are seeking the most profitable markets throughout the world.

In Bangladesh, mobile phone services are the fast growing services in telecommunication industry. This Corresponding Author: Md. Motaher Hossain, Institute of Business Admiistration, Jahangirnagar University, Savar, Dhaka, Bangladesh sector has been showing an inspiring growth for the last few years. "The number of mobile phone subscribers has steadily increased and many have begun to think that having a mobile phone is a necessary, not a luxury" (Hossain, 2010b). It is projected that Bangladesh will be the third biggest telecom market in Asia after China and India (Uddin and Akhter, 2012; Hasan, 2008). The total number of Mobile Phone subscribers has reached 98.593 million at the end of February 2013 (BTRC, 2013). More than half of the people of Bangladesh have been engaged in using mobile phone services. This enormous market coverage by Wireless Telecom Industry has proved that, though the Peoples' Republic of Bangladesh is a country of a growing economy with a very low per-capita income, buying power of customer could not impose any hinder on peoples' consumption of cellular data transmission technology's services provided by the service providing operators in this industry. Actually the market of Bangladesh, up to now, has enjoyed the 
wireless infrastructure of remote voice communication in two main methods known as Code-Division Multiple Access (CDMA) and Global System for Mobile communications (GSM).

However, there are only six service providing operators namely, 'Grameen Phone Limited (GP)', 'Banglalink Digital Communications Limited (Banglalink)', 'Robi Axiata Limited (Robi)', 'Airtel Bangladesh Limited (Airtel)', 'Teletalk Bangladesh Limited (Teletalk)' and 'Pacific Bangladesh Telecom Limited (Citycell)' in this industry. The mobile phone subscribers of different company are shown in Table 1.

Citycell is the sole service provider in CDMA method and other five operators provide services to their customers in GSM method. Mobile phone operators provide voice service and Value Added Services (VAS) including Short Message Service (SMS), Multimedia Message Service (MMS), ringtone, games, electronic transaction and web browsing. Different foreign companies: Telenor of Norway, Axiata Group Berhad of Malaysia, NTT DOCOMO INC from Japan and Abu Dhabi Group and SingTel Group were attracted to this growing market.

It is well accepted that customer satisfaction is both a goal and a marketing tool for customer-centered companies, (Kotler and Keller, 2012). Oliver (1997) defines customer satisfaction as the consumer's fulfillment response. He also considers customer satisfaction as a judgment that a product or service feature, or the product or service itself, provides a pleasurable level of consumptionrelated fulfillment. In other words, customer satisfaction is 'the customers' evaluation of a product or service in terms of whether that product or service has met their needs and expectation" (Zeithaml et al., 2008). It is believed that increasing levels of customer satisfaction can be associated with customer loyalty. "Loyalty is a deeply held commitment to rebuy or repatronize a preferred product or service in the future despite situational influences and marketing efforts having the potential to cause switching behavior" (Kotler and Keller, 2012).

The improvement of service quality, perceived value and satisfaction guarantee customer loyalty in telecom sector (Lai et al., 2009). These are the key sources of success in the business and for achieving competitive advantage. Besides, voice services proving value added services are becoming great prospect for mobile phone service providers. The customer loyalty is playing a significant role in the telecommunication market competition. Since studies regarding service quality, customer satisfaction towards services delivered by telecom operators is limited and there is no available measurement scales for service quality, especially in Bangladesh, this research paper has centered on satisfaction of customers towards different types of services offered by mobile telecom operators of Bangladesh and has analyzed the relationship of these services with loyalty in the long run.

Factors that have an impact on customer loyalty have been researched in other countries such as South Korea, Germany and France and so on. Gerpott et al. (2001) opines that network quality (which is reflected in excellent indoor and outdoor coverage and in the clarity of voice reproduction without any connection break-downs); the price paid for obtaining access to and using the network; the quality of the exchange of information between customer and operator have an important impact on customer loyalty in Germany market. Exchange of information might take place in response to customer (telephone) enquiries and in the course of interactive activities initiated by the network operator (e.g., presentation of an invoice). Lee and Cunningham (2001) considers pricing, area coverage, clarity of sound, access to provider, precision of billing service and perceived difficulty to switch are the main factors which have important impact on customer loyalty in France. Call drop rate (percentage of abnormally terminated calls), the number of complaints, providing attractive sales-promotion offerings, monthly billed amounts and customers with a non-use or suspended status are positively associated with the probability of customer churn in South Korea mobile telecom industry (Ahn et al., 2006).

Although the total number of mobile phone subscriber is increasing, the growth rate is declining. "The situation makes mobile telecommunication companies not only to promote their service quality, but also change their marketing core strategy to holding their existing customers by enhancing and optimizing the customer loyalty" (Hao et al., 2009). On the one hand, the companies have to invest quite much time and money to attract new customers and this process always go through a longer time period associated with uncertainty and risks. On the other hand, "the cost of attracting a new customer is estimated to be five times the cost of keeping a current customer happy" (Kotler and Keller, 2012). So it becomes significant for telecom companies to identify factors of services that affect on customer loyalty and in turn creates loyal customers by satisfying them in the context of Bangladesh. 
Table 1. Mobile phone subscribers of different company

\begin{tabular}{ll}
\hline Operators & Active subscribers (in millions) \\
\hline Grameen Phone Ltd. (GP) & 41.003 \\
Banglalink Digital Communications Limited & 25.848 \\
Robi Axiata Limited (Robi) & 21.291 \\
Airtel Bangladesh Limited (Airtel) & 07.300 \\
Pacific Bangladesh Telecom Limited (Citycell) & 01.459 \\
Teletalk Bangladesh Ltd. (Teletalk) & 01.692 \\
Total & 98.593 \\
\hline
\end{tabular}

Source: BTRC (2013)

This present study aims to explore the influence of customer satisfaction (towards services offered by the mobile telecom operators) on customer loyalty. Specifically, this study tries: to find out customers satisfaction with a variety of services provided by operators; to find out the interrelationship between satisfaction of services (communication, price, valueadded service, convenience, sales-promotion and customer service) and customer loyalty.

\section{MATERIALS AND METHODS}

This study is descriptive in nature. Descriptive research is used to obtain information concerning the current status of the phenomena to describe "what exists" with respect to variables or conditions in a situation (Zikmund, 2003). A conceptual model (Fig. 1) was developed to explain satisfaction of services and loyalty that directs the proposed relationship between independent and dependent variables. This relationship, then, was tested with the empirical findings.

Most data for this study were collected by means of structured questionnaire. This study also used secondary data for shaping the theoretical background and depth of knowledge. The secondary data were collected from the different journals, magazines, books and web-sites. Convenience sampling was employed to select the respondents. In total, 150 cell phone users (of different operators) of various age groups and occupation from specified areas of Dhaka city and Savar were selected as respondents.

The questionnaire had four sections. The first two sections contained the demographic characteristics and general information of the respondents: age groups, gender and occupation; duration of mobile phone usage and monthly expense for operating cell phone. The last two sections of the questionnaire included the dependent variable: customer loyalty and six independent variables- communication, price/tariff structure, value-added services, convenience, salespromotions and customer service/care. Measures for independent and dependent variables used a five-point Likert-type response format, with "strongly disagree" and "strongly agree" as the anchors. The users recorded their assessment of the items on five-point Likert-type scales ( 1 = strongly disagree, 2 = disagree, $3=$ neutral, 4 = agree, $5=$ strongly agree).

This study focused on six factors such as communication, price structure, value-added service, convenience, sales-promotions and customer service. Thus six hypotheses were used to determine the relationship between those factors and customer loyalty, considering customer loyalty as the dependent variable and other factors as independents variables:

H1: Satisfaction of communication has positive influence on customer loyalty.

$\mathrm{H} 2$ : Satisfaction of price/tariff structure has positive influence on customer loyalty.

H3: Satisfaction of value-added service has positive influence on customer loyalty.

H4: Satisfaction of convenience has positive influence on customer loyalty.

H5: Satisfaction of sales-promotion has positive influence on customer loyalty.

H6: Satisfaction of customer service/care has positive influence on customer loyalty.

Quantitative statistical techniques were used to analyze the data. This study attempted to determine the relationship (by using bi-variate linear regression) between communication and customer loyalty, price structure and customer loyalty, value-added services and customer loyalty, convenience and customer loyalty, sales-promotion and customer loyalty; customer service and customer loyalty. 


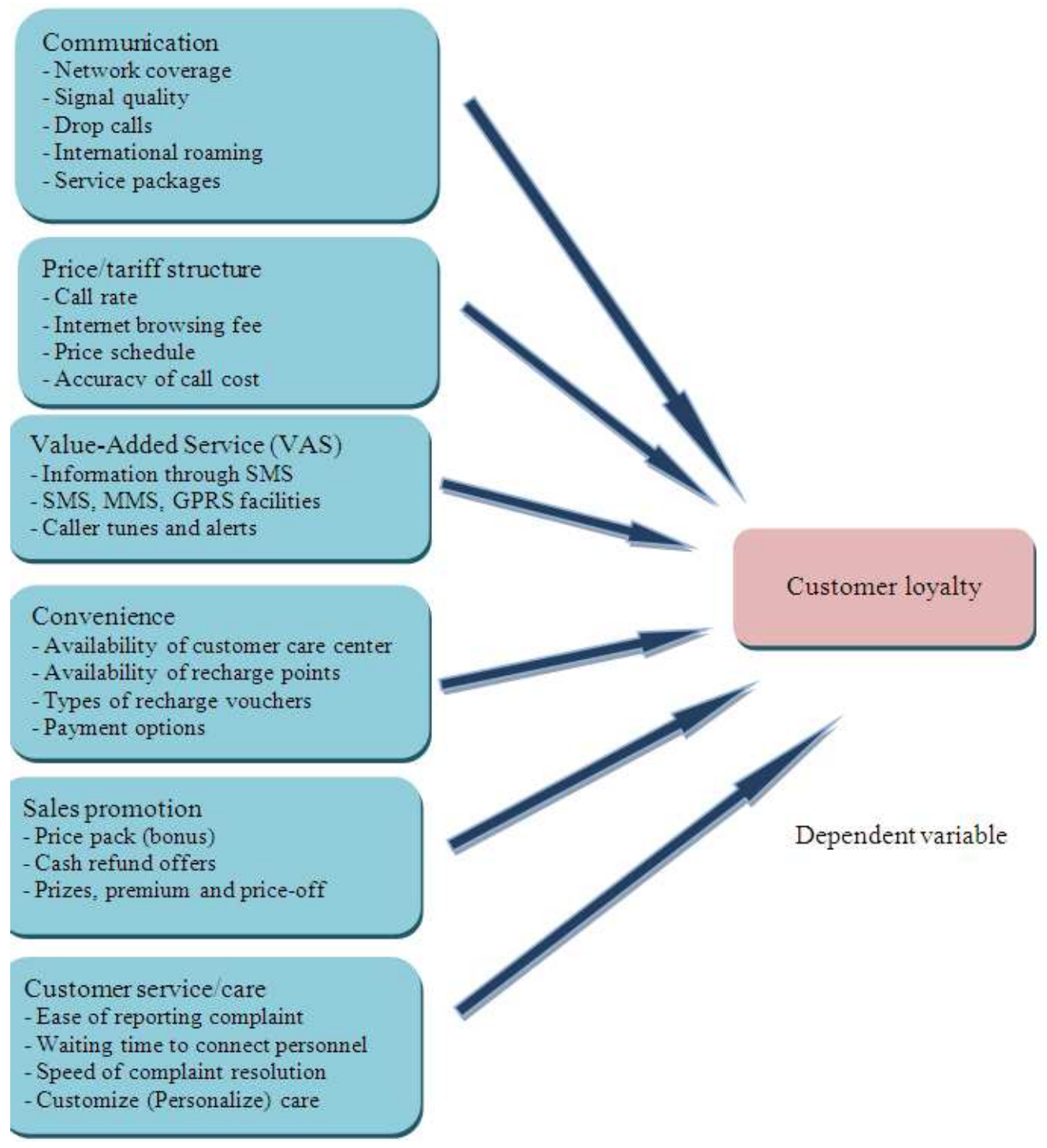

Fig. 1. Conceptual model for satisfaction of services and loyalty. Source: Developed by the authors

\section{RESULTS AND DISCUSSION}

The data collected from the respondents were analyzed to determine how the respondents reply to the different research variables investigated. Descriptive statistics and simple linear Regression were employed to analyze the data.

Table 2 shows that customer loyalty has a mean of 2.9840 and the Standard Deviation (SD) of 0.73695 . Communication has the mean of 2.6787 and SD of 0.68811. Price/tariff structure has the mean and SD of 2.8267 and 0.70231 respectively. Value-added Service has Mean of 2.7022 and standard deviation of 0.80189 . Mean of convenience is 3.1817 and SD is 0.82733 . In case of sales-promotion Mean is 2.6111 and SD is 0.66489 and finally customer service has the mean of 2.9617 and SD of 0.76508 . It has been observed in the table that almost all the mean are similar and close to each other. High standard deviation means that the data are wide spread, which means that customers give variety of opinion whereas the low standard deviation means that customers express close opinion when responding to the questionnaire provided to them. 
Table 2. Descriptive statistics

\begin{tabular}{lll}
\hline Variables & Mean & Standard Deviation (SD) \\
\hline Customer Loyalty & 2.9840 & 0.73695 \\
Communication & 2.6787 & 0.68811 \\
Price & 2.8267 & 0.70231 \\
Value-added service & 2.7022 & 0.80189 \\
Convenience & 3.1817 & 0.82733 \\
Sales-promotion & 2.6111 & 0.66489 \\
Customer service & 2.9617 & 0.76508 \\
\hline
\end{tabular}

Source: Empirical data

As mentioned earlier, the issue of customer loyalty is close to the heart of all companies, significantly important for service companies like telecommunication. Mobile telecommunications markets may be divided by the type of services provided and by the telecommunications network used (Gerpott et al., 2001), where the study deals with the influence of six service variables on customer loyalty.

To analyze the relationship between satisfaction with services offered by telecommunication companies and customer loyalty, this study tested six constructs (communication, price structure, valueadded service, convenience, sale-promotion and customer service/care) to determine loyalty of customers in the telecom market of Bangladesh. Among them five constructs (communication, price structure, value-added service, convenience and customer service/care) show positive correlations with customer loyalty, while it is evident that there is no relationship between sales-promotion and customer loyalty. Communication, price structure and valueadded service respectively are most correlated with customer loyalty in Bangladesh's telecom market.

\subsection{Communication and Loyalty}

The analysis reveals that correlation of satisfaction with communication and loyalty is positive and very important for users. Among the six independent variables, customer satisfaction with communication $(0.432)$ is most correlated with their loyalty. Most of the respondents have given emphasis on communication guarantee, negotiable call failure rates to influence loyalty. Network coverage, signal quality, uninterrupted communication, international roaming facilities are significant factors for building loyalty of telecom market of Bangladesh. Hence, telecom operators should give more emphasis on communication guarantee as customers are more sensitive about having good network coverage, signal quality, uninterrupted connection when call and international roaming facility of service operators. Most of the respondents have experienced poor network and signal quality in terms of communication. Thus, service providers should improve the techniques/technology used and increase network coverage in rural and distant locations of Bangladesh.

\subsection{Price and Loyalty}

The result of the study reveals that price/tariff plays a vital role in telecommunication market, especially for the mobile telecommunication service providers.

The correlation between price and customer loyalty is 0.399 which explains that satisfaction of customers in telecom market of Bangladesh depends on factors like attractive call rate, internet browsing fees, price schedule variation and so on. Thus price structures of the operators influence the loyalty of users a lot. Price seems one of the very significant factors to derive satisfaction and make users loyal. In this regard, operators should be more careful in determining and maintaining price structure of call and variety of services offered to customers, otherwise switching tendency of customers across operators will be increased and resulting lessening the loyalty of customers.

\subsection{Value-Added Service and Customer Loyalty}

The correlation between Value-added service and customer loyalty is 0.316 , which indicates positive relationship between these two variables. Value-added services comprises of SMS, MMS, GPRS facilities, various caller tunes and alerts offered by the service providers that rapidly come into focus and considered 
important by the users in case of constructing loyalty towards the operator of the telecom market of Bangladesh. The service providers of mobile telecom in Bangladesh should consider VAS as a rising star because more and more customers now find esteemed satisfaction by a variety of VASs and have a noteworthy influence on their usage of any operators. But the nature of services and information offered as VAS should be more rational and justified with customers' desire.

Convenience in usage and customer loyalty: In measuring customer satisfaction of telecommunication industry of Bangladesh, convenience in usage of the customers is another variable. The result of the study shows that it has weak but positive correlation of 0.179 . Therefore, it is also evident that customers' convenience to reach customer care centre and availability of recharge points and vouchers can influence customer loyalty.

\subsection{Sales-Promotion Services and Customer Loyalty}

In Bangladesh, the mobile telecom operators are intensifying their offerings in case of salespromotions (bonus, price-offs) to attract existing and new customers. But the study has brought a significant result that there is no relation between salespromotion and customer loyalty in the telecom market of Bangladesh. So with these excessive promotional efforts, operators could not able to create loyalty among customers. Sales-promotion services divert attention to financial incentives and encourage brand switching behavior, as well as increase price sensitivity which minizes the importance of quality criterion (Omotayo, 2011; Aaker, 1996). Thus, salespromotion offerings are not a determinant of creating customer loyalty.

\subsection{Customer Service/Care and Loyalty}

In Bangladesh, customer care is initially concerned with the perceptions of an organization reflected in associations with reaching customers. The study shows that correlation between customer service/care and loyalty is positive $(0.270)$ where customer service can be defined as a system of activities that comprises customer support systems, ease of reporting and speed of processing complaint; friendliness when reporting complaint. The promptness of all these activities grounds for creating customer loyalty towards the service operator in the telecom market of Bangladesh. Moreover in the mobile telecommunication industry, the high levels of competition among service providers call for adoption of different customer service techniques to satisfy and retain customers that have practical relation with building loyalty of customers according to the study. Although customer service/care is a comparatively new practice of mobile telecom operators in Bangladesh but their presences have partially influenced customer loyalty. So, more cordial and expertise service through training of personnel's of telecom companies can help deriving customer retention for using a particular operator as their service attitude and work efficiency play an important role in the service quality.

As mentioned earlier, five hypotheses: communication and customer loyalty; price/tariff structure and customer loyalty; value-added service and customer loyalty; convenience and customer loyalty; and customer service and customer loyalty were accepted (Table 3). So, in order to create and enhance customer loyalty mobile operators should emphasize more on those services which are considered as significant by the users. The companies should concentrate more on their users' needs and modify the marketing strategies to retain the customers.

Table 3. Summary of hypotheses test

\begin{tabular}{lll}
\hline S/N & Hypotheses & Status \\
\hline 1. & Satisfaction of communication has positive influence on customer loyalty & Accepted \\
2. & Satisfaction of price/tariff structure has positive influence on customer loyalty & Accepted \\
3. & Satisfaction of value-added service has positive influence on customer loyalty & Accepted \\
4. & Satisfaction of convenience has positive influence on customer loyalty & Accepted \\
5. & Satisfaction of sales-promotion has positive influence on customer loyalty & Rejected \\
6. & Satisfaction of customer service/care has positive influence on customer loyalty & Accepted \\
\hline
\end{tabular}




\section{CONCLUSION}

Many telecom companies have embarked on a journey of positioning through the communication channel to build strong customer loyalty and sustain in the competitive market. Potential to retain the current customers and make them loyal to its brands is a very critical issue for the persistent success of service companies (Achour et al., 2012; Ahmad and Buttle, 2002). Loyal customers buy more, pay premium prices and provide new referrals through positive word of mouth over time and hence they build the business (Achour et al., 2012; Ganesh et al., 2000; Oliver, 1999). Therefore, customer loyalty in services like telecom is an important area to study.

Our analysis in this study explained that attributes of services have influence on creating customer loyalty that enables telecom companies to gain more market share. The mobile service providers of Bangladesh need to modify several concerns that enable them to catch the attention of customers and keep them loyal in the long run. It has been well known that customers' perceived service quality and satisfaction have been the most important success factors of business competition for either manufacturers or service providers (Munusamy et al., 2010; Buzzell and Gale, 1987). Satisfaction towards services has been widely studied as a predictor of customer loyalty either in retaining or attracting customers. Thus, the importance of satisfaction is very crucial for the telecom companies in Bangladesh.

This study analyzed the relationship between customer loyalty and satisfaction towards various services of mobile telecommunication industry of Bangladesh. Mobile telecom industry is the most competitive among all service industries in Bangladesh where customer satisfaction plays a significant role. Many argue that loyalty of customers is always important for companies to generate profit. In such a scenario, it is momentous to know about the services delivered by telecom operators' influence on user's loyalty. The findings of this study revealed that communication, price, value-added service, convenience in usage and customer service are positively related to customer loyalty. Interestingly enough, the study revealed that sales-promotion is not related to the customer loyalty. The situation can be explained by the general characteristics of Bangladesh's mobile phone market. Since the purchasing power of subscribers in
Bangladesh is less than the subscribers in developed countries, call quality, coverage of area and service quality of service center and hotline are important to customer loyalty in general. Because of low price and encouraging value-added services, these services appear important for telecom users of Bangladesh.

The result of this study has important managerial implications: managers of mobile telecommunication industry of Bangladesh can apply the findings to manage their business and improve their services quality. This study is also important from the academic perspective. The causal relationship is established by performing an empirical analysis of the influence of customer satisfaction on loyalty. This study recognizes the need for further research in this field.

\section{REFERENCES}

Aaker, J.L., 1996. The malleable self: The role of selfexpression in persuasion. J. Mark. Res., 36: 45-58. DOI: $10.2307 / 3151914$

Achour, M., N.P.M. Said and A. Boerhannueddin, 2012. Customer loyalty: The case of mobile phone users in universiti Utara Malaysia. Int. J. Manage. Stud., 18: 43-66.

Ahmad, R. and F. Buttle, 2002. Customer retention management: A reflection of theory and practice. Market. Intell. Plann., 20: 149-161. DOI: $10.1108 / 02634500210428003$

Ahn, J. H., S.P. Han and Y.S. Lee, 2006. Customer churn analysis: Churn determinants and mediation effects of partial defection in the Korean mobile telecommunications service industry. Telecommun. Policy, 30: 552-569. DOI: 10.1016/j.telpol.2006.09.006

BTRC, 2013. Mobile phone subscribers in Bangladesh. Bangladesh Telecommunication Regulatory Commission.

Buzzell, R.D. and B.T. Gale, 1987. The Profit Impact of Market Strategy (PIMS) Principles: Linking Strategy to Performance. 1st Edn., Free Press, New York, ISBN-10: 0029044308, pp: 322.

Ganesh, J., M.J. Arnold and K.E. Reynolds, 2000. Understanding the customer base of service providers: An examination of the differences between switchers and stayers. J. Market., 64: 65-87.

Gerpott, T.J., W. Rams and A. Schindler, 2001. Customer retention, loyalty and satisfaction in the German mobile cellular telecommunications market. Telecommun. Policy, 25: 249-269. DOI: 10.1016/S0308-5961(00)00097-5 
Hao, Y., X. Yuan and W. Zhang, 2009. How to Promote Customer Loyalty of Chinese Mobile Telecom Operator: Case Study of China Mobile. Blekinge Institute of Technology.

Hasan, M., 2008. An overview of telecommunication market of Bangladesh. The Daily Star.

Hossain, M.M., 2010a. Changing consumption patterns in rural Bangladesh. Int. J. Consumer Stud., 34: 349356. DOI: 10.1111/j.1470-6431.2010.00866.x

Hossain, M.M., 2010b. Role of technology in consumption and everyday life in rural Bangladesh. Technol. Soc., 32: 130-136. DOI: 10.1016/j.techsoc.2010.03.004

Kotler, P. and K.L. Keller, 2012. Marketing Management. 14th Edn., Prentice-Hall, Harlow, ISBN-10: 0273755021.

Lai, F., M. Griffin and B. Babin, 2009. How quality, value, image and satisfaction create loyalty at a Chinese telecom. J. Bus. Res., 62: 980-986. DOI: 10.1016/j.jbusres.2008.10.015

Lee, M. and L.F. Cunningham, 2001. A cost/benefit approach to understanding service loyalty. J. Services Market., 15: 113-130. DOI: 10.1108/08876040110387917
Munusamy, J., S. Chelliah and H.W. Mun, 2010. Service Quality Delivery and its Impact on Customer Satisfaction in the Banking Sector in Malaysia. Int. J. Innovat. Technol., 1: 398-404.

Oliver, R.L., 1997. Satisfaction: A Behavioral Perspective on the Consumer. 1st Edn., McGrawHill, New York, ISBN-10: 0071154124, pp: 432.

Oliver, R.L., 1999. Whence Consumer Loyalty? J. Mark., 63: 33-44. DOI: 10.2307/1252099

Omotayo, O., 2011. Sales promotion and consumer loyalty: A study of Nigerian tecommunication industry. J. Competitiveness, 4: 66-77.

Uddin, M.B. and B. Akhter, 2012. Customer satisfaction in mobile phone services in Bangladesh: A survey research. Manage. Market., 10: 20-36.

Zeithaml, V.A., M.J. Bitner, D.D. Gremler and A. Pandit, 2008. Services Marketing: Integrating Customer Focus Across the Firm. 5th Edn., McGraw-Hill Irwin, Boston, ISBN-10: 0071263934, pp: 708.

Zikmund, W.G., 2003. Business Research Methods. 7th Edn., Thomson/South-Western, Mason, ISBN-10: 0324182392, pp: 748. 